\title{
Review
}

\section{Neuropathological Staging of Brain Pathology in Sporadic Parkinson's disease: Separating the Wheat from the Chaff}

\author{
Heiko Braak* and Kelly Del Tredici \\ Department of Neurology, Clinical Neuroanatomy Section, Center for Biomedical Research, University of Ulm, \\ Ulm, Germany
}

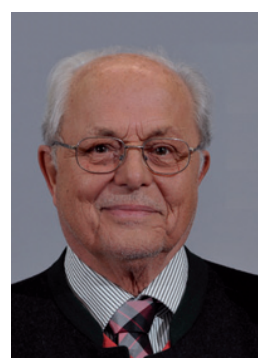

Prof. Heiko Braak, M.D., A native of Kiel, Germany, Braak completed medical school at the University of Kiel, receiving his doctorate in 1964. After the habilitation in anatomy (1970), he became Professor of Anatomy there (1974). As Visiting Professor of Neurology at Harvard Medical School (1978/79), he worked with Norman Geschwind and published the monograph Architectonics of the Human Telencephalic Cortex (1980). From 1980 until 2002, Braak directed the Institute for Clinical Neuroanatomy at the Dr. Senckenberg Anatomical Institute of the Goethe University Frankfurt/Main. After retiring from university teaching, he was appointed Guest Researcher (2002) at the Goethe University until moving to Ulm University (2009), where he is a Senior Professor. He is recipient of the Robert A. Pritzker Prize for Leadership in Parkinson's Disease Research, awarded by the Michael J. Fox Foundation (2014), and of the Annemarie Opprecht Parkinson Prize (2015). Interests: tauopathies, PD pathogenesis, ALS, pathoarchitectonics of the human brain.

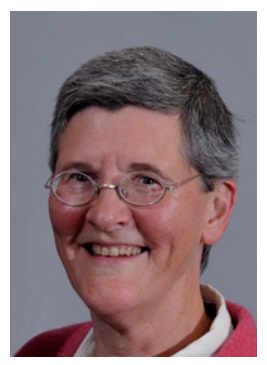

Kelly Del Tredici, M.D., Ph.D., A native of San Francisco, Del Tredici came to Germany on a Fredrick Sheldon Traveling Fellowship from Harvard University (1989) after studying classical languages at Loyola University of Chicago (1970-1974) and Fordham University in New York City (1976-1982). She completed medical school at the Goethe University Frankfurt/Main (2003), receiving her doctorate in neuroanatomy there in 2004. Del Tredici was a medical resident at the Clinic for Psychiatry and Neurology in Winnenden (near Stuttgart) until 2006, when she became a postdoctoral fellow at the Dr. Senckenberg Anatomical Institute (Institute for Clinical Neuroanatomy, Goethe University). She moved to Ulm University (2009), where she is a Senior Research Fellow. She is married to Heiko Braak. Interests: neuroanatomy, PD pathogenesis, tauopathies, ALS.

\footnotetext{
${ }^{*}$ Correspondence to: Prof. Heiko Braak, M.D., Center for Biomedical Research, University of Ulm, Helmholtzstrasse 8/1, 89081 Ulm, Germany. Tel.: +49 73150063111 ; Fax: +49 731500 63133; E-mail: heiko.braak@uni-ulm.de.
} 


\begin{abstract}
A relatively small number of especially susceptible nerve cell types within multiple neurotransmitter systems of the human central, peripheral, and enteric nervous systems (CNS, PNS, ENS) become involved in the degenerative process underlying sporadic Parkinson's disease (sPD). The six-stage model we proposed for brain pathology related to sPD (Neurobiol Aging 2003) was a retrospective study of incidental and clinically diagnosed cases performed on unconventionally thick tissue sections $(100 \mu \mathrm{m})$ from a large number of brain regions. The staging model emphasized what we perceived to be a sequential development of increasing degrees of Lewy pathology in anatomically interconnected regions together with the loss of aminergic projection neurons in, but not limited to, the locus coeruleus and substantia nigra. The same weight was assigned to axonal and somatodendritic Lewy pathology, and the olfactory bulb was included for the first time in a SPD staging system. After years of research, it now appears that the earliest lesions could develop at nonnigral (dopamine agonist nonresponsive) sites, where the surrounding environment is potentially hostile: the olfactory bulb and, possibly, the ENS. The current lack of knowledge regarding the development of Lewy pathology within the peripheral autonomic nervous system, however, means that alternative extra-CNS sites of origin cannot be disregarded as possible candidates. The PD staging system not only caused controversy but contributed a framework for (1) assessing pathology in the spinal cord, ENS, and PNS in relationship to that evolving in the brain, (2) defining prodromal disease and cohorts of at-risk individuals, (3) developing potential prognostic biomarkers for very early disease, (4) testing novel hypotheses and experimental models of $\alpha$-synuclein propagation and disease progression, and (5) finding causally-oriented therapies that intervene before the substantia nigra becomes involved. The identification of new disease mechanisms at the molecular and cellular levels indicates that physical contacts (transsynaptic) and transneuronal transmission between vulnerable nerve cells are somehow crucial to the pathogenesis of sPD.
\end{abstract}

Keywords: $\alpha$-synuclein, autonomic nervous system, cell-to-cell transfer, central nervous system, dorsal motor nucleus of the vagal nerve, enteric nervous system, Lewy body disease, locus coeruleus, Parkinson's disease, olfactory bulb, peripheral nervous system, prion-like, protein aggregation, protein misfolding, spinal cord, substantia nigra

"It therefore is worthwhile to examine the Lewy bodies, find out what they are composed of, and what molecular events precede and accompany their formation. Once we know that, will we be able to prevent Lewy bodies from forming? And if Lewy bodies do not form, will we then have no substantia nigra degeneration and no Parkinson's disease? Perhaps that is too much to expect from Lewy's peculiar cellular inclusions.” L.S. Forno [1].

Fredrick Lewy's descriptions of the pathology associated with paralysis agitans were not confined to the substantia nigra [2], and these were expanded upon by later investigators, who recognized that Parkinson's disease is a multisystem and autonomic system disorder, during the course of which circumscribed subcortical nuclei, cortical areas, spinal cord structures, and portions of the peripheral and enteric nervous system become involved [3-10]. In 1997, the presynaptic protein $\alpha$-synuclein was discovered to be a major component of Lewy bodies and neurites in the substantia nigra of sPD and dementia with Lewy bodies (DLB) [11]. Reports of $\alpha$-synuclein in pale bodies, axons [12,13], dot-like structures [14], and in punctate cytoplasmic inclusions [15] rapidly followed.

In Frankfurt, our group had been studying sPD since the early 1990's with a focus on the lesions in the amygdala and other extranigral regions of the human brain [16-18]. Gradually, three questions emerged: (1) Does sPD begin in the substantia nigra or elsewhere $[17,19]$ ? (2) Do vulnerable regions in all divisions of the human nervous system become involved at the same time? (3) Does the distribution of Lewy pathology in susceptible nonnigral regions follow a recognizable pattern or sequence [20]?

These questions can be answered only when biomarkers of the underlying degenerative process $[21,22]$, electrophysiological testing, and imaging modalities make it possible to assess and reassess one and the same individual at ongoing time points in life [23-26]. Neuropathologists necessarily perform cross-sectional studies that (ideally) include not only clinically diagnosed SPD but also prodromal SPD and incidental cases [27-29] to gain knowledge about the regional distribution and severity of the pathology, its progression and possible spreading, neurodegeneration, and nerve cell loss. The same limitations inherent in cross-sectional studies also apply to the procedures proposed for the neuropathological diagnosis and staging of Lewy body disease [20, 30-35].

Reactions to the six-stage grading model have been essentially encouraging [36-40], although the following anecdote is illustrative of the climate in which some of the earlier differences of opinion took place. In August 2009, we received an email from an American colleague of a newly published experimental study: "In the discussions with the authors and editors, it was suggested to take out the references to your work so that our paper could be published .... I am not sure why your findings are 
so controversial and bring up such strong emotions." Controversies surrounding the staging publication [20] crystalized chiefly around the following points:

1. Inasmuch as DLB belongs to the spectrum of Lewy body diseases, the staging should have been performed not only on SPD but also on DLB cases. The staging of sPD does not 'fit' DLB.

We ventured to postulate that DLB cases might overlap with sPD stages 5 and 6 [41; see also 42] and that a phase of mild cognitive impairment could precede overt dementia in SPD [41, 43, 44], which can be accompanied by the presence of severe Alzheimer's-related pathology. Nevertheless, the sPD staging concept was never intended for DLB $[45,46]$, and during the peer review process, we were explicitly requested to include the following caveats for the reader: "... the study sample does not include cases clinically diagnosed as diffuse Lewy body disease... It remains to be seen whether deviations from the proposed staging scheme exist in cases of advanced AD with Lewy bodies or in cases of clinically assessed diffuse Lewy body disease" [20].

2. PD staging does not apply to 'amygdalapredominant' cases.

Within the context of approximately $43-60 \%$ of late-stage $\mathrm{AD}$ cases, Lewy pathology can be mainly or even solely confined to the amygdala [47-50], especially in the 'corticomedial' regions of the amygdala, including the central and cortical subnuclei [47]. The basolateral subnuclei (which become involved during stage 3 after the central subnucleus in SPD; see [20]) were also evaluated, but the degree of the involvement there was not further specified [47]. Later, it could be seen that, in 17/66 AD cases with NFT stages V-VI and amygdala-predominant Lewy pathology, anterior olfactory structures, including the olfactory bulb, were $\alpha$-synuclein-immunoreactive [51-53]. Inasmuch as it is unlikely that such amygdala-predominant cases represent prodromal sPD [54] and probably constitute a neuropathologically distinct synucleinopathy [47], it is not surprising that they are not stageable - nor, in retrospect, were cases of amygdala-predominant pathology included in our sPD staging study sample [20].

3. Clinical symptoms and the clinical course of disease do not correspond to the proposed neuropathological stages and it is unlikely that older persons with incidental Lewy pathology would have gone on to be diagnosed with PD.
Most individuals in our sample with Lewy pathology corresponding to stages 1-3 were older than 60 years of age and, thus, on average older than those representing SPD stages 4-6, where neurological impairment was present or would be expected $[20,38]$. The assumption, however, that at least some of those at stages 1-3 who were between 54 and 71 years of age [20] would have developed SPD had they survived longer is in line with the results and demographics from several other cross-sectional or prospective hospital- and university-based cohorts [55-59] as well as a study of 139 longitudinally followed elderly controls [60] (Fig. 1a-d). For the first time, the olfactory bulb was included as a diagnostic region for staging sPD [20], and in more recent studies of at-risk or prodromal persons, e.g., with olfactory lesions and hyposmia compared to controls, as well as of individuals with Lewy pathology in gastrointestinal biopsies and/or constipation (i.e., autonomic dysregulation), some not only were older than 60 but subsequently converted to SPD [61-65; see also 66, 67].

Gibb and Lees [68] pointed out that some of the most influential neuropathological studies on SPD provided too little, if any, clinical data, and this also applied to Lewy's own studies. For staging purposes, we had access to neuropathological and clinical datasets, including the cause of death, for the majority of cases with clinically diagnosed SPD, whereas for a few cases with incidental Lewy pathology this information was unavailable [20]. Because SPD as a cause of death may be underreported [69], it cannot be ruled out that some of these 'incidental' cases were at or beyond the threshold to early but yet undiagnosed SPD with subtle motor symptoms.

We emphasized that a biological continuиm exists from the preclinical (silent) through the prodromal to the clinical phase $[20,45,70,71]$. Do the sPD neuropathological stages we proposed have any bearing on the clinical symptoms and disease courses seen by neurologists in their patients? Our impression is yes, and we see the staging model as a useful framework for longitudinal autopsy-controlled correlation studies [72-74], for models of possible propagation and routes of spreading (see below), for the development of possible biomarkers during the preclinical and prodromal phases [61, 75-77], and for potential therapeutic strategies of symptoms consistent with early pathology and with even earlier changes within the protein $\alpha$-synuclein $[38,75,78-82]$. As new research results continue to emerge, other groups inevitably will winnow out and discard what is incorrect or 


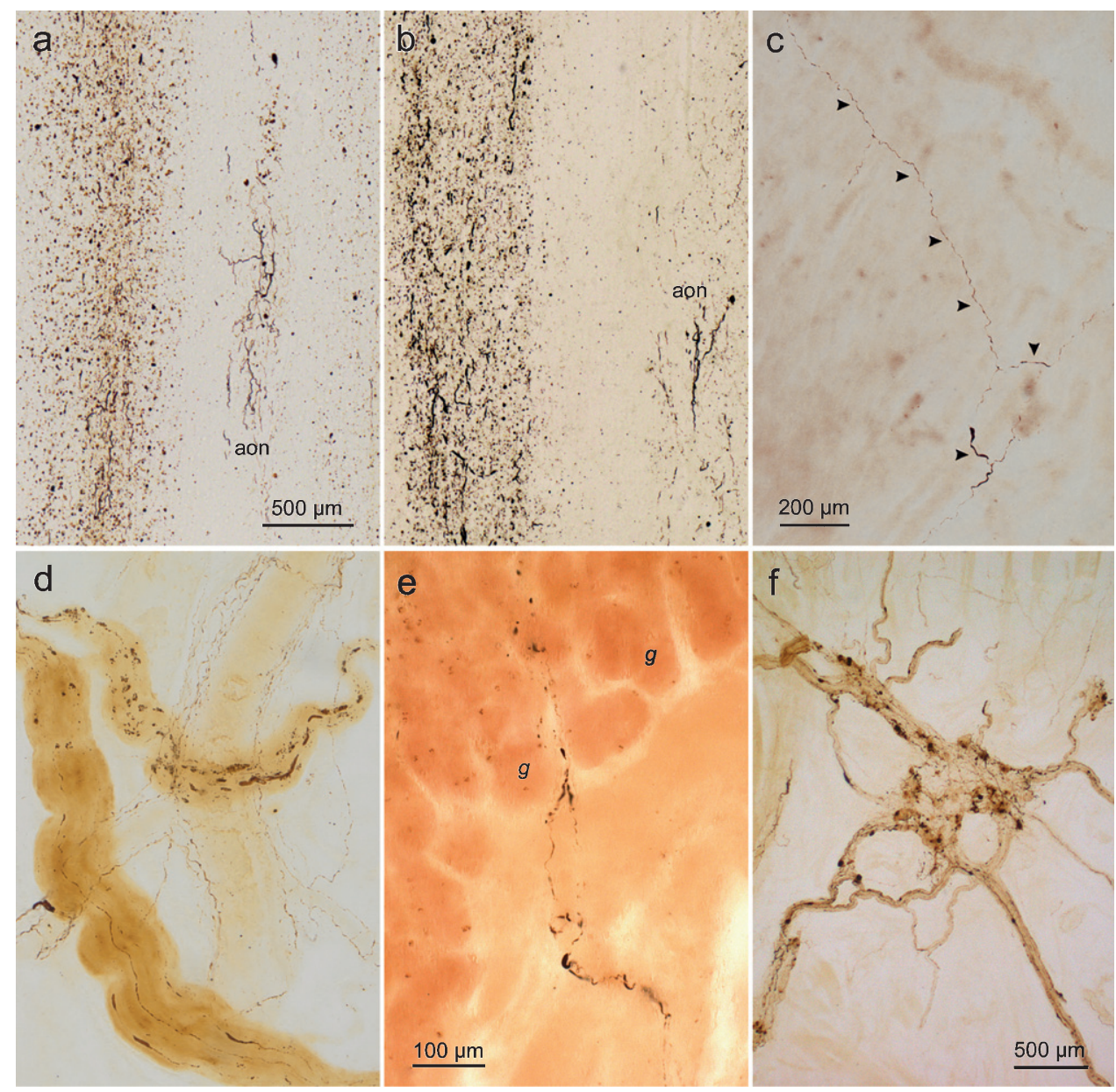

Fig. 1. (a-f) Lewy pathology in the olfactory bulb and gastric Auerbach plexus visualized in $\alpha$-synuclein immunohistochemistry (100 $\mu \mathrm{m}$ polyethylene glycol sections). a. Olfactory bulb and anterior olfactory nucleus (aon) (50-year-old male, stage 2). The dorsal motor nucleus of the vagal nerve and intermediate reticular zone in the medulla also contained Lewy neurites and Lewy bodies. Presumably, this non-demented individual would have gone on to develop PD had he lived longer. b. Olfactory bulb and aon (63-year-old female, stage 2). Much less severe pathology was also present in the dorsal motor nucleus of the vagal nerve, intermediate reticular zone, nucleus raphes magnus, and locus coeruleus. c. Tangential section from the gastric cardia showing Lewy neurites (arrowheads, same case as in b). Again, it is presumed that, had she lived longer, this cognitively intact individual would have been diagnosed with PD. d. Intramural Lewy pathology in a section cut tangentially to the surface of the gastric cardia. Also visible (in background) is a large, branching blood vessel lined by thread-like immunoreactive sympathetic nerve fibers. In addition to the occurrence of Lewy neurites and Lewy bodies in the dorsal motor nucleus of the vagal nerve, intermediate reticular zone, nucleus raphes magnus, locus coeruleus, and substantia nigra, some nigral cell loss was also evident in the pars compacta (65-year-old male, stage 3). e. Detail of Lewy neurites in PD penetrating the muscularis mucosa and reaching upwards into the lamina propria (mucosa) where they extend between the gastric glands $(g)$ in a perpendicularly cut section (69-year-old female, stage 4). f. Tangential section from the gastric cardia of a PD patient with disease duration of 11 years (78-year-old female, stage 5). Scale bars: $\mathbf{a}$ is valid for $\mathbf{b} ; \mathbf{c}$ also applies to $\mathbf{d}$. Stages in parentheses refer to neuropathological stages 1-6 of sporadic PD. Micrographs e, $\mathbf{f}$ reproduced with permission from [70].

obsolete while keeping the relevant and valid aspects of the staging system.

4. Staging based on the presence of Lewy pathology (e.g., pale bodies, Lewy bodies, Lewy neurites) rather than on neuronal loss or other evidence of neurodegenerative change is not admissible. The presence and distribution patterns of Lewy pathology in nondopaminergic neurons during SPD could be attributable to localized, regional vulnerabilities and the Lewy pathology might be neuroprotective rather than deleterious.

Inasmuch as the prodromal symptoms and vulnerable neuronal types in SPD and DLB are remarkably similar, i.e., Lewy pathology in limbic and neocortical regions correlate equally well with dementia in SPD and in DLB [12, 83, 84], it is odd that the 
pathological status of Lewy pathology is questioned within the context of sPD but not DLB. Similarly, why do clinical symptoms in DLB (but not those in sPD-related dementia) reportedly parallel the numbers of Lewy bodies rather than nerve cell loss in the limbic system and, above all, in the neocortex $[85,86]$ ?

That the protein $\alpha$-synuclein is pathogenic in SPD is shown by the fact that duplication or triplication of the wild-type $\alpha$-synuclein gene also causes a familial form of PD, in which increased levels of even the normal protein are sufficient to trigger disease accompanied by Lewy body formation [87, 88]. Postmitotic cells may produce somatic Lewy bodies as an adaptive measure [89]. If so, however, this presumably is not because the nerve cells with such inclusions fail to recognize them as abnormal (and, thus, destined for elimination) but because the physiological cellular systems responsible for clearing soluble defective proteins and fibrillar aggregates probably become dysfunctional during sPD [90-95]. Multiple Lewy bodies that nearly fill a single cell soma are unlikely, in the long term, to be 'protective'. Moreover, depletion of cytoplasmic tyrosine hydroxylase or of choline acetyltransferase and their sequestration within Lewy bodies [96] make these enzymes unavailable for the neuromodulation of essential brain functions [97, 98]. Too little is currently known about the stages at which neurotransmitter deficits develop or when they manifest themselves clinically [99]. Postural instability and gait problems in SPD, for example, appear to be related to cholinergic and glutaminergic rather than dopaminergic nerve cell and neurotransmitter loss $[100,101]$

The presence of $\alpha$-synuclein aggregates in the somatodendritic compartment represents an abnormal localization of a protein that physiologically occurs in presynaptic terminals $[102,103]$ following its production in the neuronal soma [81, 104]. Lewy neurites in the axoplasm may interfere with cellular homeostasis $[105,106]$ and, although it is unknown to what extent animal models of Lewy-like neurodegeneration accurately reflect mechanisms of the sPD disease process within the human nervous system [107-113], it has been shown that synthetic $\alpha$-synuclein fibrils as well as Lewy pathology extracts derived from human brains contribute to punctate changes in wild-type mice and in rhesus monkeys without the genetic overexpression of $\alpha$-synuclein $[114,115]$.

That Lewy pathology (particularly Lewy neurites) are closely associated with neurodegeneration in SPD is evident in that nonnigral regions with susceptible nerve cell types are subject to premature neuronal loss $[20,71]$ : These include the dorsal motor nucleus of the vagal nerve, with its preganglionic neurons that supply dense parasympathetic innervation of the distal esophagus and stomach [116], the locus coeruleus $[6,20,117-121]$, the pedunculopontine nucleus [118, $121,122]$, and Meynert's nucleus in the basal forebrain $[6,123]$. Attenuated sPD staging protocols are practical and perhaps unavoidable for routine diagnostic use on thin tissue sections $(6-10 \mu \mathrm{m})$ but they can make it possible to underestimate Lewy pathology severity and the degree of nerve cell loss within distinct regions (e.g., the interstitial nucleus of the diagonal band) at different stages [20].

We ascribed the same weight to axonopathy and nerve cell dysfunction (presumably attributable, but not limited, to the presence of Lewy pathology) as to neuronal death $[20,46]$ because the development of pathology together with neurotransmitter loss [96, 121, 124-132], axonal, and somatodendritic dysfunction in multiple neuronal populations could prove to be more stressful for involved neurons over time than premature cell death within a select neuronal population $[46,71,133]$. Viewed from this perspective, the thick network of Lewy neurites that gradually forms during SPD in the CA2/CA3 sectors of the Ammon's horn [20, 71, 134] and the severe Lewy pathology seen in the lower and upper raphe systems, magnocellular nuclei of the basal forebrain, the hypothalamic tuberomamillary nucleus, and the intralaminar nuclei of the thalamus are not negligible lesions [71]. Staging based on the presence and distribution of Lewy pathology rather than on nerve cell loss also makes sense for another reason: Effective longterm neuron-to-neuron spreading of $\alpha$-synuclein [135-137] presupposes the existence of sufficient numbers of at least minimally intact nerve cells and intact circuitries [138, 139].

One of the most controversial aspects of the staging classification is the concept of a caudorostral trajectory of pathology in the brain $[20,38,70]-$ although, upon somewhat closer inspection, our concept and that of McKeith et al. [32] can be seen to rest on the same basic assumption as Kosaka's tripartite model [30]: namely, that Lewy pathology progresses systematically and topographically in a generally caudal to rostral trajectory [33]. An important difference between our staging model and that proposed for DLB, however, is that we included the presence of cortical Lewy neurites and not only cortical Lewy bodies [20]. Although the staging concept cannot 
answer the important question whether dopaminergic and susceptible nonnigral neurons are all subject to the same pathogenic mechanisms in SPD [38, 140-142], we believe that the study of regional vulnerabilites is meaningful only within the context of neuronal networks (connectivities) and not in isolation. Were it to become possible one day to 'rescue' somehow dopaminergic neurons, the neuronal dysfunction and nerve cell loss within other involved susceptible long-axoned nonnigral projection cells would remain, presumably, unabated [71, 143].

Once the disease process begins, it may not proceed as a sweeping 'wave' to end-stage sPD [144, 145] but with a degree of inter-individual variability that partially depends on the rate at which seeding of very small $\alpha$-synuclein aggregates and, above all, the rate at which regional spread of Lewy pathology occurs within the nervous system of each individual. After $\alpha$ synuclein seeding, the neuropathology that emerges probably develops over a much longer time period, thereby implying a timelag or threshold between the development of Lewy pathology in a given nucleus or neuronal population and the emergence of detectable functional deficits [75, 146]. Thus, nonunitary (nonlinear) rates of progression do not necessarily imply a nonunitary pathogenesis of sPD [147].

In the same year that our group's staging article appeared, we speculated in a second publication that a neurotropic pathogen, possibly a virus, with access to the olfactory bulb and gastrointestinal tract, might trigger abnormal changes in the protein $\alpha$-synuclein: "Such a pathogen could possess unconventional prion-like properties and might consist of misfolded $\alpha$-synuclein molecular fragments [148]." At that time, the idea was so speculative we thought it might never be published.

Neuron-to-neuron transfer of pathogenic $\alpha$ synuclein aggregates was demonstrated for the first time in humans when fetal neuronal grafts developed Lewy pathology more than a decade after surgery [135-137; see also 149] and when experimental models made it possible to detect seeding mechanisms of $\alpha$-synuclein aggregates [109, 150-152]. The current and disputed hypothesis of a 'prionlike' dissemination of $\alpha$-synuclein being explored by many PD research groups [153] is that a pathogenic (i.e., aggregation-prone) form of the protein can self-assemble into oligomers and fibrils, transfer into another nerve cell, recruit the endogenous $\alpha$-synuclein there, and instigate the gradual but virtually indefinite self-propagation of new insoluble $\alpha$-synuclein aggregates [146, 154-162]. The existence of different conformers or 'strains' lends additional credence to the prion-like properties of $\alpha$ synuclein [163, 164; but see 165]. It remains to be seen whether different strains also differ with respect to their pathogenicity, spreading propensities, and accumulation patterns.

Such neuron-to-neuron propagation of $\alpha$ synuclein during aging may partially explain the predictable topographical distribution pattern of Lewy pathology and the neurodegeneration we described in different, but anatomically (axonally) interconnected, populations of susceptible projection neurons in the human brain [20, 166; see also 167]. The earliest sPD-related lesions within the nervous system appear to develop in the olfactory bulb, dorsal motor nucleus of the vagal nerve, and possibly also the ENS [19, 20, 56, 127, 133, 148, 168]. At two of these sites, the surrounding environment is potentially hostile to projection neurons with long unmyelinated axons [133, 148, 169-171, 171a] because both the olfactory bulb as well as the intramucosal nerve fibers of the gastrointestinal tract are easily accessible conduits for neurotropic viruses [172-174] that could cause the initial conformational change in a-synuclein.

We reasoned that, after entering vulnerable local projection neurons of the intramural plexuses (Fig. 1e, f), $\alpha$-synuclein aggregates might reach unmyelinated axons of the vagal nerve and, from there, via retrograde axonal transport the preganglionic visceromotor neurons of the dorsal motor nucleus [148, 169, 170, 175]. In experiments with intraduodenal, intragastric, and peripheral vagal nerve inoculations [176-178], some of the results reported are consistent not only with regional spreading within the nervous system. Vagotomy, on the other hand, halted the progression [179]. Similarly, vagotomy severely reduced the innervation of the ENS in a study of normative and abnormal patterns of $\alpha$-synuclein expression in specific subsets of enteric neurons and vagal efferents of the rat proximal myenteric plexus [180; see also 181, 182].

The results derived from experimental models have received support from epidemiologic evaluations of vagotomies, which formerly were performed to treat peptic ulcers [183]. Full vagotomy, with resection of both vagal trunks, differs from selective vagotomy, which involves resection of only terminal branches of the vagal nerve that supply the fundus and corpus of the stomach [183; see also 184-186]. This illustrates that the risk of having developed SPD at followup more than ten years after surgical intervention 
was significantly reduced in individuals who had undergone full truncal vagotomy but remained nearly similar to the risk of the general population in persons with selective vagotomy [183].

Additional routes of Lewy pathology transmission from the intramural plexus of the ENS to the central nervous system are conceivable, including via retrograde axonal transport to postanglionic sympathetic projection neurons in the prevertebral celiac ganglion and from there to preganglionic sympathetic neurons in layer 7 (intermediolateral nucleus) and nociceptive neurons in layer 1 of the spinal cord dorsal horn [187; see also 9, 56, 176, 188]. Alternatively, $\alpha$-synuclein aggregates originating in the ENS could be transmitted via the celiac ganglion and layer 7 to the level-setting nuclei of the lower brainstem and from there anterogradely to noradrenergic neurons within the dorsal vagal area (A1 group) and within the intermediate reticular zone (A2 group) $[14,71]$.

Whether the pathogenic process in incidental and prodromal cases proceeds in a retrograde direction (ENS > central nervous system), in an anterograde direction (CNS > ENS), or reciprocally, still has to be proved [188]. Presumably, however, inasmuch as seeding can take place in both retrograde and anterograde directions [109, 115, 189], anterograde prion-like propagation of Lewy pathology along preganglionic projection neurons of the dorsal motor nucleus of the vagal nerve via cholinergic vagal efferents to the intramural plexus of the gastrointestinal tract is anatomically conceivable [189a]. Until now, only a single study showing intraneuronal changes first in the dorsal motor nucleus of the vagal nerve, followed by chiefly varicose neuritic changes in the myenteric plexus of the stomach and duodenum exists [190]. Once again, however, vagotomy interrupted the anterograde spread of $\alpha$-synuclein in this animal model [190].

Some of the earliest detectable Lewy pathology in stage 1 cases occurs in the olfactory bulb [20], and the finding that brain involvement can be confined to the olfactory bulb [34] or to anterior olfactory structures only (glomerula, olfactory mucosa) [168] prompted new hypotheses to test possible spreading routes in sPD. For instance, a recent axonal tracing study delineated the existence of an anterograde pathway between the substantia nigra and the olfactory bulb in rats [191]. In another scenario, retrograde transport and transsynaptic transmission of Lewy pathology could take place early in the disease course from anterior olfactory structures to the amygdala or to the level-setting nuclei, including the locus coeruleus
[192-194], possibly before pathology originating in the ENS could reach the dorsal motor nucleus of the vagal nerve. In stage 4 of our staging model, amgydala Lewy pathology is followed by the initial appearance of cortical lesions in the transentorhinal region [20], which is lacking in non-primates. This may account for why routes beyond the amygdala [169] taken by viruses or by $\alpha$-synuclein inoculates in an animal model [195] are not directly comparable to the routes accessible in humans. Alternatively, a latent neurotropic virus in the locus coeruleus or amygdala might become reactivated there but use either site only as a 'transit center' with the initial development of Lewy pathology taking place elsewhere, i.e., in anterior olfactory structures $[194,196]$. The theory of a neurotropic virus that utilizes a 'keylock' mechanism to invade unprotected nerve cell fibers could explain why - among a multitude of vertebrates - only the human species develops SPD. The pathogen would need to deactivate endogenous chaperones and cause $\alpha$-synuclein to undergo a stable (albeit pathological) conformation [197, 198] prior to prion-like propagation.

Knowledge about the distribution and development of Lewy pathology in the peripheral autonomic nervous system during SPD is still remarkably limited. Previous observers, however, reported in incidental SPD cases a differential distribution and density of $\alpha$-synuclein aggregates in sympathetic (cardiac and vesicoprostatic) versus parasympathetic neurons or networks [10, 23, 56, 126, 127 129, 199, 200]. Thus, as further potential extra-CNS sites of disease origin, the cardiac sympathetic nerves and the postganglionic neurons of the paravertebral sympathetic ganglia, with possible subsequent prion-like spreading of $\alpha$-synuclein to the spinal cord [201], require further investigation. Within the spinal cord, the Lewy pathology that develops in the preganglionic intermediolateral nucleus and the sacral parasympathetic nucleus of layer 7, beginning in PD stage 2, could also originate in neurons of the supraspinal level-setting nuclei, including the locus coeruleus, and terminate in the visceromotor autonomic centers of layer 7 via anterograde axonal transport [56, 188, 202].

In closing, we still have many unanswered questions and we see that many issues remain disputed. Nevertheless, there has also been progress, not the least owing to morphological and neuropathological studies, with implications and practical consequences for diagnostics and therapies of prodromal sPD symptoms. The more we understand about the mechanisms 
underlying the conformational change and aggregation of the protein $\alpha$-synuclein and about the anatomically interconnected regions with their susceptible nerve cells at all levels, the greater is our hope that a causal therapy (or therapies) for sPD can be found. Because experimental cell models approximate the milieu found in the human nervous system, where Lewy pathology develops in projection neurons with a long life expectancy, we wonder if a human ENS cell model might yield valuable insights into the mechanisms of $\alpha$-synuclein aggregation and transmission [133]. Resected tissue culled from surgical interventions on the human gastrointestinal tract, for example, contains functional groups of susceptible post-mitotic myenteric plexus nerve cells [203; see also 204]. We also are interested to learn what results might be yielded by experiments and animal models involving human-derived $\alpha$-synuclein and Lewy pathology from nonnigral sites. Do the seeding and spreading behaviors resemble or differ from those observed when using nigral extracts or inoculates?

\section{ACKNOWLEDGMENTS}

The authors dedicate this article to Professor Lysia S. Forno in admiration of her pioneering pathoanatomical work. They are also especially grateful to the members of the Michael J. Fox Foundation and the Robert A. Pritzker family, the Annemarie Opprecht Foundation (Bern, Switzerland), Albert C. Ludolph, MD, and all of the families and patients who, by means of brain and organ donations, made the neuropathological staging of Parkinson's disease and subsequent staging-related projects possible.

\section{CONFLICTS OF INTEREST}

The authors have no current or potential conflicts of interest to report.

\section{REFERENCES}

[1] Forno LS (1960) The Lewy body in Parkinson's disease. Adv Neurol, 45, 35-43.

[2] Lewy FH (1913) Zur pathologischen Anatomie der Paralysis agitans. Dtsch $Z f$ Nervenheilk, 50, 50-55.

[3] den Hartog Jager WA, \& Bethlem J (1960) The distribution of Lewy bodies in the central and autonomic nervous systems in idiopathic paralysis agitans. J Neurol Neurosurg Psychiatry, 23, 283-290.

[4] Forno LS, \& Norville RL (1976) Ultrastructure of Lewy bodies in the stellate ganglion. Acta Neuropathol, 34, 183-197.
[5] Langston JW, \& Forno LS (1978) The hypothalamus in Parkinson disease. Ann Neurol, 3, 129-133.

[6] Jellinger K (1991) Pathology of Parkinson's disease. Changes other than nigrostriatal pathway. Mol Chem Neuropathol, 14, 153-197.

[7] Wakabayashi K, Takahashi H, Takeda S, Ohama E, \& Ikuta F (1988) Parkinson's disease: The presence of Lewy bodies in Auerbach's and Meissner's plexuses. Acta Neuropathol, 76, 217-221.

[8] Daniel SE, \& Hawkes CH (1992) Preliminary diagnosis of Parkinson's disease by olfactory bulb pathology. Lancet, 340, 186.

[9] Wakabayashi K, \& Takahashi H (1997) The intermediolateral nucleus and Clarke's column in Parkinson's disease. Acta Neuropathol, 94, 287-289.

[10] Iwanaga K, Wakabayashi K, Yoshimoto M, Tomita I, Satoh H, takashima H, Satoh A, Seto M, Tsujhata M, \& Takahashi H (1999) Lewy body-type degeneration in cardiac plexus in Parkinson's and incidental Lewy body diseases. Neurology, 52, 1269-1271.

[11] Spillantini MG, Schmidt ML, Lee VM, Trojanowski JQ, Jakes R, \& Goedert M (1997) Alpha-synuclein in Lewy bodies. Nature, $\mathbf{3 8 8}, 839-840$.

[12] Irizarry MC, Whittfield G, Gomez-Isla T, Newell K, George JM, Clayton DF, \& Hyman BT (1998) Nigral and cortical Lewy bodies and dystrophic nigral neurites in Parkinson's disease and cortical Lewy body disease contain $\alpha$-synuclein immunoreactivity. $J$ Neuropathol Exp Neurol, 57, 334-337.

[13] Braak H, Sandmann-Keil D, Gai W, \& Braak E (1999) Extensive axonal Lewy neurites in Parkinson's disease: A novel pathological feature revealed by alpha-synuclein immunocytochemistry. Neurosci Lett, 265, 67-69.

[14] Braak H, Rüb U, Sandmann-Keil D, Gai WP, de Vos RA, Jansen Steur EN, Arai K, \& Braak E (2000) Parkinson's disease: Affection of brain stem nuclei controlling premotor and motor neurons of the somatomotor system. Acta Neuropathol, 99, 489-495.

[15] Kuusisto E, Parkkinen L, \& Alafuzoff I (2003) Morphogenesis of Lewy bodies: Dissimilar incorporation of alpha-synuclein, ubiquitin, and p62. J Neuropathol Exp Neurol, 62, 1241-1253.

[16] Braak H, Braak E, Yilmazer D, de Vos RA, Jansen EN, Bohl J, \& Jellinger K (1994) Amygdala pathology in Parkinson's disease. Acta Neuropathol, 88, 493-500.

[17] Braak H, Braak E, Yilmazer D, Schultz C, de Vos RA, \& Jansen EN (1995) Nigral and extranigral pathology in Parkinson's disease. J Neural Transm Suppl, 46, 15-31.

[18] Braak H, Braak E, Yilmazer D, de Vos RAI, Jansen ENH, \& Bohl J (1996) Pattern of brain destruction in Parkinson's and Alzheimer's diseases. J Neural Transm, 103, 455-490.

[19] Del Tredici K, Rüb U, de Vos RA, Bohl JR, \& Braak H (2002) Where does Parkinson disease pathology begin in the brain? J Neuropathol Exp Neurol, 61, 413-426.

[20] Braak H, Del Tredici K, Rüb U, de Vos RA, Jansen Steur EN, \& Braak E (2003) Staging of brain pathology related to sporadic Parkinson's disease. Neurobiol Aging, 24, 197-211.

[21] Dickson DW, Fujishiro H, Orr C, DelleDonne A, Josephs KA, Frigerio R, Burnett M, Parisi JE, Klos KJ, \& Ahlskog JE (2009) Neuropathology of non-motor features of Parkinson disease. Parkinsonism Rel Disord, 15(Suppl 3), S1-S5.

[22] Lang AE (2011) A critical appraisal of the premotor symptoms of Parkinson's diasease: Clinical 
features and detection strategies. Mov Disord, 26, 775-783.

[23] Minguez-Castellanos A, Chamorro CE, EscamillaSevilla F, Ortega-Moreno A, Rebollo AC, Gomez-Rio M, Concha A, \& Munoz DG (2007) Do a-synuclein in autonomic plexuses predate Lewy body disorders? Neurology, 68, 2012-2018.

[24] Siderowf A, Jennings D, Eberly S, Oakes D, Hawkins KA, Ascherio A, Stern MB, Marek K, \& PARS Investigators (2012) Impaired olfaction and other prodromal features in the Parkinson At-Risk Syndrome Study. Mov Disord, 27, 406-412.

[25] Jennings D, Siderowf A, Stern M, Seibyl J, Eberly S, Oakes D, Marek K, \& PARS Investigators (2014) Neurology, 83, 1739-1746.

[26] Lerche S, Seppi K, Behnke S, Liepelt-Scarfone I, Godau J, Mahlknecht P, Gaenslen A, Brockmann, Srulijes K, Huber H, Wurster I, Stockner H, Kiechel S, Willeit J, Gasperi A, Fassbender K, Poewe W, \& Berg D (2014) Risk factors and prodromal markers and the development of Parkinson's disease. J Neurol, 261, 180-187.

[27] Forno LS (1969) Concentric hyalin intraneuronal inclusions of Lewy type in the brain of elderly persons (50 incidental cases): Relationship to parkinsonism. $J$ Am Geriatr Soc, 17, 557-575.

[28] Wakabayashi K, Takahashi H, Oyanagi K, \& Ikuta F (1993) Incidental occurrence of Lewy bodies in the brains of elderly patients - the relevance to aging and Parkinson's disease. No To Shinkei, 45, 1033-1038.

[29] Frigerio R, Fujishiro H, Ahn TB, Josephs KA, Maraganore DM, DelleDonne A, Parisi JE, Klos KJ, Boeve BF, Dickson DW, \& Ahlskog JE (2011) Incidental Lewy body disease: Do some cases represent a preclinical stage of dementia with Lewy bodies? Neurobiol Aging, 32, 857-863.

[30] Kosaka K, Tsuchiya K, \& Yoshimura M (1988) Lewy body disease with and without dementia: A clinicopathological study of 35 cases. Clin Neuropathol, 7, 299-305.

[31] Marui W, Iseki E, Nakai T, Mirua S, Kato M, Uéda K, \& Kosaka K (2002) Progression and staging of Lewy pathology in brains from patients with dementia with Lewy bodies. J Neurol Sci, 195, 153-159.

[32] McKeith IG, Dickson DW, Lowe J, Emre M, O'Brien JT, Feldman H, et al. (2005) Diagnosis and management of dementia with Lewy bodies: Third report of the DLB Consortium. Neurology, 65, 1863-1872.

[33] Alafuzoff I, Ince PG, Arzberger T, Al-Sarraj S, Bell J, Bodi I, et al. (2009) Staging/typing of Lewy body related alpha-synuclein pathology: A study of the BrainNet Europe Consortium. Acta Neuropathol, 117, 635-652.

[34] Beach TG, Adler CH, Lue L, Sue LI, Bachalakuri J, Henry-Watson J, et al. (2009) Unified staging system for Lewy body disorders: Correlation with nigrostriatal degeneration, cognitive impairment and motor dysfunction. Acta Neuropathol, 117, 613-634.

[35] Montine TJ, Phelps CH, Beach TG, Bigio EH, Cairns NJ, Dickson DW, et al. (2012) National Institute on Aging-Alzheimer's Association guidelines for the neuropathologic assessement of Alzheimer's disease: A practical approach. Acta Neuropathol, 123, 1-11.

[36] Dickson DW, Uchikado H, Fujishiro H, \& Tsuboi Y (2010) Evidence in favor of Braak staging of Parkinson's disease. Mov Disord, 25(Suppl 1), S78-S82.

[37] van de Berg WD, Hepp DH, Dijkstra AA, Rozemuller JA, Berendse HW, \& Foncke E (2012) Patterns of alphasynuclein pathology in incidental cases and clinical subtypes of Parkinson's disease. Parkinsonsim Relat Disord, 18(Suppl 1), S28-S30.

[38] Halliday G, McCann H, \& Shepherd C (2012) Evaluation of the Braak hypothesis: How far can it explain the pathogenesis of Parkinson's disease? Expert Rev Neurother, 12, 673-686.

[39] Jenner P, Morris HR, Robbins TW, Goedert M, Hardy J, Ben-Shlomo Y, Bolam P, David Burn D, Hindle JV, Brooks D, \& for the Parkinson's UK Discussion Group (2013) Parkinson's disease-the debate on the clinical phenomenology, aetiology, pathology and pathogenesis. J Parkinsons Dis, 3, 1-11.

[40] Dijkstra AA, Voorn P, Berendse HW, Groenewegen HJ, Netherlands Brain Bank, Rozemuller AJ, \& van de Berg WD (2014) Stage-dependent nigral neuronal loss in incidental Lewy body and Parkinson's disease. Mov Disord, 29, 1244-1251.

[41] Braak H, Rüb U, Jansen Steur EN, Del Tredici K, \& de Vos RAI (2005) Cognitive status correlates with neuropathologic stage in Parkinson disease. Neurology, 64, 1404-1410.

[42] Jellinger KA (2003) Alpha-synuclein pathology in Parkinson's and Alzheimer's disease brain: Incidence and topographic distribution - a pilot study. Acta Neuropathol, 106, 191-201.

[43] Molano J, Boeve B, Ferman T, Smith G, Parisi J, Dickson D, Knopman D, Graff-Redford N, Geda Y, Lucas J, Kantarci K, Shiung M, Jack C, Silber M, Shane Pankratz V, \& Petersen R (2010) Mild cognitive impairment associated with limbic and neocortical Lewy body disease: A clinicopathological study. Brain, 133, 540-556.

[44] Litvan I, Goldman JG, Tröster AI, Schmand BA, Weintraub D, Petersen RC, Mollenhauser B, Adler CH, Marder K, Williams-Gray CH, Aarsland D, Kulisevsky J, Rodriguez-Oroz MC, Burn DJ, Barker RA, \& Emre M (2012) Diganostic criteria for mild cognitive impairment in Parkinson's disease: Movement Disorder Society Task Force Guidelines. Mov Disord, 27, 349-356.

[45] Braak H, Bohl JR, Müller CM, Rüb U, de Vos RAI, \& Del Tredici K (2006a) Stanley Fahn Lecture 2005: The staging procedure for the inclusion body pathology associated with sporadic Parkinson's disease reconsidered. Mov Disord, 12, 2041-2051.

[46] Del Tredici K, \& Braak H (2012) Lewy pathology and neurodegeneration in premotor Parkinson's disease. Mov Disord, 27, 597-607.

[47] Uchikado H, Lin WL, DeLucia MW, \& Dickson DW (2006) Alzheimer disease with amygdala Lewy bodies: A distinct form of alpha-synucleinopathy. J Neuropathol Exp Neurol, 65, 685-697.

[48] Hamilton RL (2000) Lewy bodies in Alzheimer's disease: A neuropathological review of 145 cases using alpha-synuclein immunohistochemistry. Brain Patho, 10, 378-384.

[49] Saito Y, Kawashima A, Ruberu NN, Fujiwara H, Koyama $\mathrm{S}$, Sawabe M, Arai T, Nagura H, Yamanouchi $\mathrm{H}$, Hasegawa M, Iwatsubo T, \& Murayama S (2003) Accumulation of phosphorylated $\alpha$-synuclein in aging human brain. J Neuropathol Exp Neurol, 62, 644-654.

[50] Zaccai J, Brayne C, McKeith I, Matthews F, \& Ince PG (2008) Patterns and stages of alpha-synucleinopathy: Relevance in a population-based cohort. Neurology, 70, 1042-1048.

[51] Braak H, Müller CM, Rüb U, Ackermann H, Braztke H, de Vos RAI, \& Del Tredici K (2006) Pathology associated 
with sporadic Parkinson disease - where does it end? J Neural Transm Suppl, 70, 89-97.

[52] Fujishiro H, Tsuboi Y, Lin WL,Uchikado H, \& Dickson DW (2008) Colocalization of tau and alpha-synuclein in the olfactory bulb in Alzheimer's disease with amygdala Lewy bodies. Acta Neuropathol, 116, 17-24.

[53] Sengoku R, Saito Y, Ikemura M, Hatsuta H, Sakiyama Y, Kanemaru K, Arai T, Sawabe M, Tanaka N, Mochizuki H, Inoue K, \& Murayama S (2008) Incidence and extent of Lewy body-related $\alpha$-synucleinopathy in aging human olfactory bulb. J Neuropathol Exp Neurol, 67, 10721083.

[54] Dickson DW, Braak H, Duda JE, Duyckaerts C, Gasser T, Halliday GM, Hardy J, Leverenz JB, Del Tredici K, Wszolek Z, \& Litvan I (2009) Neuropathological assessment of Parkinson's disease: Refining the diagnostic criteria. Lancet Neurol, 8, 1150-1157.

[55] Abbott RD, Petrovitch H, White LR, Masaki KH, Tanner CM, Curb JD, Grandinetti A, Blanchette PL, Popper JS, \& Ross GW (2001) Frequency of bowel movements and the future risk of Parkinson's disease. Neurology, 57, 456-462.

[56] Bloch A, Probst A, Bissig H, Adams H, \& Tolnay M (2006) Alpha-synuclein pathology of the spinal cord and peripheral autonomic nervous system in neurologically unimpaired elderly subjects. Neuropathol Appl NeuroBiol, 32, 284-295.

[57] DelleDonna A, Klos KJ, Fujishiro H, Ahmed Z, Parisi JE, Josephs KA, Frigerio R, Burnett M, Wszolek ZK, Uitti RJ, Ahlskog JE, \& Dickson DW (2008) Incidental Lewy body disease and preclinical Parkinson's disease. Arch Neurol, 65, 1074-1080.

[58] Dickson DW, Fujishiro H, DelleDonne A, Menke J, Zeshan A, Klos K, Josephs KA, Frigerio R, Burnett M, Parisi JE, \& Ahlskog JE (2008) Evidence that incidental Lewy body disease is presymptomatic Parkinson's disease. Acta Neuropathol, 115, 437-444.

[59] Petrovitch H, Abbott RD, Ross GW, Nelson J, Masaki KH, Tanner CM, Launer LJ, \& White LR (2009) Bowel movement frequency in late-life and substantia nigra neuron density at death. Mov Disord, 24, 371-376.

[60] Markesbery WR, Jicha GA, Liu H, \& Schmitt FA (2009) Lewy body pathology in normal elderly subjects. $J \mathrm{Neu}$ ropathol Exp Neurol, 68, 816-822.

[61] Shannon KM, Keshavarzian A, Mutlu E, Dodiya HB, Jakate S, \& Kordower JH (2012) Is alpha-synuclein in the colon a biomarker for premotor Parkinson's disease? Mov Disord, 27, 716-719.

[62] Driver-Dunkley E, Adler CH, Hentz JG, Dugger BN, Shill HA, Caviness JN, Sabbagh MN, Beach TG, \& Arizona Parkinson Disease Consortium (2014) Olfactory dysfunction in incidental Lewy body disease and Parkinson's disease. Parkinsonism Relat Disord, 20, 1260-1262.

[63] Hilton D, Stephens M, Kirk L, Edwards P, Potter R, Zajicek J, Broughton E, Hagan H, \& Carroll C (2014) Accumulation of $\alpha$-synuclein in the bowel of patients in the pre-clinical phase of Parkinson's disease. Acta Neuropathol, 127, 235-241.

[64] Iranzo A, Gelpi E, Tolosa E, Molineuvo JL, Serradell M, Gaig C, \& Santamaria J (2014) Neuropathology of prodromal Lewy body disease. Mov Disord, 29, 410-415.

[65] Stokholm MG, Danielsen EH, Hamilton-Dutoit SJ, \& Borghammer P (2016) Pathological $\alpha$-synuclein in gas- trointestinal tissues from prodromal Parkinson disease patients. Ann Neurol, 79, 940-949.

[66] de Rijk MC, Launer LJ, Breteler MM, Dartigues JF, Baldereschi M, Fratiglioni L, Lobo A, Martinez-Lage J, Trenkwalder C, \& Hofman A (2000) Prevalence of Parkinson's disease in Europe: A collaborative study of population-based cohorts. Neurology, 54(Suppl 5), 2123.

[67] Pringsheim T, Jette N, Frolkis A, \& Steeves TD (2014) The prevalence of Parkinson's disease: A systematic review and meta-analysis. Mov Disord, 29, 1583-1590.

[68] Gibb WRG, \& Lees AJ (1994) Pathological clues to the cause of Parkinson's disease. In: Marsden C, \& Fahn S (eds) Movement Disorders 3rd ed, Oxford: ButterworthHeinemann, Ltd, pp. 147-166.

[69] Benito-León J, Louis ED, Villarejo-Galende A, Romero JP, \& Bermejo-Pareja F (2014) Under-reporting of Parkinson's disease on death certificates: A populationbased study (NEDICES). J Neurol Sci, 347, 188-192.

[70] Braak H, \& Del Tredici K (2008) Nervous system pathology in sporadic Parkinson disease. Neurology, 70, 1916-1925.

[71] Braak H, \& Del Tredici K (2009) Neuroanatomy and pathology of Parkinson's disease. Adv Anat Embryol Cell Biol, 201, 1-120.

[72] Fujishiro H, Frigerio R, Burrnett M, Klos KJ, Josephs KA, Delledonne A, Parisi JE, Ahlskog JE, \& Dickson DW (2008) Cardiac sympathetic denervation correlates with clinical and pathologic stages of Parkinson's disease. Mov Disord, 23, 1085-1092.

[73] Iranzo A, Tolosa E, Gelpi E, Molineuvo JL, Valldeoriola F, Serradell M, Sánchez-Valle R, Vilaseca I, Lomeña F, Vilas D, Lladó A, Gaig C, \& Santamaria J (2013) Neurodegenerative disease status and post-mortem pathlogy in idiopathic rapid-eye-movement sleep behaviour disorder: An observational color study. Lancet Neurol, 12, 443-453.

[74] Iranzo A, Fernández-Arcos A, Tolosa E, Serradell M, Molineuvo JL, Valldeoriola F, Gelpi E, Vilaseca I, Sánchez-Valle R, Lladó A, Gaig C, \& Santamaria J (2014) Neurodegenerative disorder risk in idiopathic REM sleep behavior disorder: Study in 174 patients. PLoS One, 9, e89741.

[75] Boeve BF (2013) Idiopathic REM sleep behavior disorder in the development of Parkinson's disease. Lancet Neurol, 12, 469-482.

[76] Vilas D, Iranzo A, Tolosa E, Aldecoa I, Bereguer J, Vilasecca I, Martí C, Serradell M, Lomeña F, Alós L, Gaig C, Santamaria J, \& Gelpi E (2016) Assessment of $\alpha$-synuclein in submandibular glands of patients with idiopathic rapid-eye-movement sleep behaviour disorder: A case-control study. Lancet Neurol, 15, 708-718.

[77] Vivacqua G, Latorre A, Suppa A, Nardi M, Pietracupa S, Mancinelli R, Fabbrini G, Colosimo C, Gaudio E, \& Beradelli A (2016) Abnormal salivary total and oligomeric alpha-synuclin in Parkinson's disease. PLoS One, 11, e0151156.

[78] Langston JW (2006) The Parkinson's complex: Parkinsonism is just the tip of the iceberg. Ann Neurol, 59, 591-596.

[79] Schapira A, \& Tolosa E (2010) Molecular and clinical prodrome of Parkinson disease: Implications for treatment. Nat Rev Neurosci, 6, 309-317.

[80] Olanow CW, \& Obeso JA (2012) The significance of defining preclinical or prodromal Parkinson's disease. Mov Disord, 27, 666-669. 
[81] Lashuel HA, Overk CR, Ouestlati A, \& Masliah E (2013) The many faces of $\alpha$-snyuclein: From structure and toxicity to therapeutic target. Nat Rev Neurosci, 14, 38-48.

[82] Dehay B, Bourdenx M, Gorry P, Przedborski S, Vila M, Hunot S, Singleton A, Olanow CW, Merchant KM, Bezard E, Petsko GA, \& Meissner WG (2015) Targeting $\alpha$-synuclein for treatment of Parkinson's disease: Mechanistic and therapeutic considerations. Lancet Neurol, 14, 855-866.

[83] Hurtig HI, Trojanowski JQ, Galvin J, Ewbank D, Schmidt ML, Lee VM, Clark CM, Glosser G, Stern MB, Gollomp SM, \& Arnold SE (2000) Alpha-synuclein Lewy bodies correlate with dementia in Parkinson's disease. Neurology, 54, 1916-1921.

[84] Tsuboi Y, \& Dickson DW (2005) Dementia with Lewy bodies and Parkinson's disease with dementia: Are they different? Parkinsonism Relat Disord, 11(Suppl 1), S47S51.

[85] Esiri MM, McShane RH. Parkinson's disease and dementia. In: Esiri MM, \& Morris JH (eds) The Neuropathology of Dementia. Cambridge: Cambridge University Press, 1997, pp. 174-193.

[86] Lennox GG, \& Lowe J. Dementia with Lewy bodies. In: Markesbery WR (ed) Neuropathology of Dementing Disorders. London: Arnold, 1998, pp. 181-192.

[87] Singleton AB, Farrer M, Johnson J, Singleton A, Hague S, Kachergus J, Hulihan M, Peuralinna T, Dutra A, Nussbaum R, Lincoln S, Crawley A, Hanson M, Maraganore D, Adler C, Cookson MR, Muenter M, Baptista M, Miller D, Blancato J, Hardy J, \& Gwinn-Hardy K (2003) alphaSynuclein locus triplication causes Parkinson's disease. Science, 302, 841.

[88] Ibáñez P, Bonnet AM, Débarges B, Lohmann E, Tison F, Pollak P, Agid Y, Dürr A, \& Brice A (2004) Causal relation between alpha-synuclein gene duplication and familial Parkinson's disease. Lancet, 364, 1169-1171.

[89] Tanaka M, Kim YM, Lee G, Junn E, Iwatsubo T, \& Mouradian MM (2004) Aggresomes formed by alphasynuclein and syniphilin-1 are cytoprotective. J Biol Chem, 279, 4625-4631.

[90] Chung KK, Dawson VL, \& Dawson TM (2001) The role of the ubiquitin-proteosomal pathway in Parkinson's disease and other neurodegenerative disorders. Trends Neurosci, 24, 7-14.

[91] Cuervo AM, Stefanis L, Fredenburg R, Lansbury PT, \& Sulzer D (2004) Impaired degradation of mutant $\alpha$ synuclein by chaperone-mediated autophagy. Science, 305, 1292-1295.

[92] Jaeger PA, \& Wyss-Coray T (2009) All-you-can-eat: Autophagy in neurodegeneration and neuroprotection. Mol Neurodeger, 4, 16.

[93] Lynch-Day M, Mao K, Wang K, Zhao M, \& Klionsky DJ (2012) The role of autophagy in Parkinson's disease. Cold Spring Harb Perspect Med, 2, a009357.

[94] Dehay B, Martinez-Vicente M, Caldwell GA, Caldwell KA, Yue Z, Cookson MR, Kelin C, Vila M, \& Bezard E (2013) Lysosomal impairment in Parkinson's disease. Mov Disord, 28, 725-732.

[95] Miki Y, Tanji K, Mori F, Utsumi J, Sasaki H, Kakita A, Takahashi H, \& Wakabayashi K (2015) Alteration of upstream autophagy-related proteins (ULK1, ULK2, Beclin 1, VPS34, and AMBRA1) in Lewy body disease. Brain Patho, 26, 359-370.

[96] Dugger BN, \& Dickson SW (2010) Cell-type sequestration of choline acetyltransferase and tyrosine hydroxylase within Lewy bodies. Acta Neuropathol, 120, 633-639.

[97] Usher M, Cohen JD, Servan-Schreiber D, Rajowksi J, \& Aston-Jones G (1999) The role of the locus coeruleus in the regulation of cognitive performance. Science, $\mathbf{2 8 3}$, 549-554.

[98] Sara SJ (2009) The locus coeruleus and noradrenergic modulation of cognition. Nat Rev Neurosci, 10, 211-223.

[99] Pavese N, Rivero-Bosch M, Lewis SJ, Whone AL, \& Brooks DJ (2011) Progression of monoaminergic dysfunction in Parkinson's disease: A longitudinal 18F-dopa PET study. Neuroimage, 56, 1463-1468.

[100] Pahapill PA, \& Lozano AM (2000) The pedunculopontine nucleus and Parkinson's disease. Brain, 123, 1767-1783.

[101] Karachi C, Grabli D, Bernard FA, Tandé D, Wattiez N, Belaid H, Bardinet E, Prigent A, Nothacker HP, Hunot S, Hartmann A, Lehéricy S, Hirsch EC, \& Francois C (2010) Cholinergic mesencephalic neurons are involved in gait and postural disorders in Parkinson disease. J Clin Invest, 120, 2745-2754.

[102] Iwai A, Yoshimoto M, Masliah E, \& Saitoh T (1995) The precursor protein of non-A beta component of Alzheimer's disease amyloid is a presynaptic protein of the central nervous system. Neuron, 14, 467-475.

[103] Tanji K, Mori F, Mimura J, Itho K, Kakita A, Takahashi H, \& Wakabayashi K (2010) Proteinase K-resistant synuclein is deposited in presynapses in human Lewy body disease and A53T $\alpha$-synuclein transgenic mice. Acta Neuropathol, 120, 2894-2905.

[104] Fortin DL, Nemani VM, Voglmaier SM, Anthony MD, Ryan TA, \& Edwards RH (2005) Neural activity controls the synaptic accumulation of $\alpha$-synuclein. Neurobiol Dis, 25, 10913-10921.

[105] Saha AR, Hill J, Utton MA, Asuni AA, Ackerley S, Grierson AJ, Miller CC, Davies AM, Buchanan VL, Anderton BH, \& Hanger DP (2004) Parkinson's disease alphasynuclein mutations exhibit defective axonal transport in cultured neurons. J Cell Sci, 117, 1017-1024.

[106] Volipicelli-Daley LA, Gamble KL, Schultheiss CE, Riddle DM, West AB, \& Lee VM (2014) Formation of $\alpha$ synuclein Lewy neurite-like aggregates in axons impedes the transport of distinct endosomes. $\mathrm{Mol} \mathrm{Biol} \mathrm{Cel,} \mathrm{25,}$ 4010-4023.

[107] Giasson BI, Duda JE, Quinn SM, Zhang B, Trojanowski JQ, \& Lee VM (2002) Neuronal alpha-synucleinopathy with severe movement disorder in mice expressing A53T human alpha-synuclein. Neuron, 34, 521-533.

[108] Neumann M, Kahle PJ, Giasson BI, Ozmen L, Borroni E, Spooren W, Müller V, Odoy S, Fujiwara H, Hasegawa M, Iwatsubo T, Trojanowski JA, Kretzschmar HA, \& Haass C (2002) Misfolded proteinase Kresistant hyperphosphorylated alpha-synuclein in aged transgenic mice with locomotor deterioration and in human alpha-synucleinopathies. J Clin Invest, 110, 1429-1439.

[109] Volpicelli-Daley LA, Luk KC, Patel TP, Tanik SA, Riddle DM, Stieber A, Meaney DF, Trojanowski JQ, \& Lee VM (2011) Exogenous $\alpha$-synuclein fibrils induce Lewy body pathology leading to synaptic dysfunction and neuron death. Neuron, 72, 57-71.

[110] Mougenot AL, Nicot S, Bencsik A, Morignat E, Verchère J, Lakhdar L, Legastelois S, \& Baron T (2012) Prion-like acceleration of a synucleinopathy in a transgenic mouse model. Neurobiol Aging, 33, 2225-2228. 
[111] Bernis ME, Babila JT, Breid S, Wüsten KA, Wüllner U, \& Tamgüney G (2015) Prion-like propagation of human brain-derived $\alpha$-synuclein in transgenic mice expressing wild-type $\alpha$-synuclein. Acta Neuropathol Comm, 3, 75.

[112] Schweighauser M, Bacioglu M, Fritschi SK, Shimshek DR, Kahle PJ, Eisele YS, \& Jucker M (2015) Formaldehye-fixed brain tissue from sponataneously ill alpha-synuclein transgenic mice induces fatal alphasynucleinopathy in transgenic hosts. Acta Neuropathol, 129, 157-159.

[113] Breid S, Bernis ME, Babita JT, Garza MC, Wille H, \& Tamgüney G (2016) Neuroinvasion of $\alpha$-synuclein prionoids after intraperitoneal and intraglossal inoculation. J Virol, 90, 9182-9193.

[114] Luk KC, Kehm V, Carroll J, Zhang B, O'Brien P, Trojanowski JQ, \& Lee VM (2012) Pathological $\alpha$-synuclein transmission initiates Parkinson-like neurodegeneration in nontransgenic mice. Science, 338, 949-953.

[115] Recasens A, Dehay B, Bové J, Carballo-Carbajal I, Dovero S, Pérez-Villalba A, Fernagut PO, Blesa J, Parent A, Perier C, Fariñas I, Obeso JA, Bezard E, \& Vila M (2014) Lewy body extracts from Parkinson's disease brains trigger $\alpha$-synuclein pathology and neurodegeneration in mice and monkeys. Ann Neurol, 75, 351-362.

[116] Halliday GM, Blumbergs PC, Cotton RGH, Blessing WW, \& Geffen LB (1990) Loss of brainstem serotoninand substance P-containing neurons in Parkinson's disease. Brain Res, 510, 104-107.

[117] Tomonaga M (1983) Neuropathology of the locus coeruleus: A semi-quantitative study. J Neurol, 230, 231240.

[118] Halliday GM, Li YW, Blumbergs PD, Joh TH, Cotton RG, Howe PR, Blessing WW, \& Geffen LB (1990) Neuropathology of immunohistochemically identified brainstem neurons in Parkinson's disease. Ann Neurol, 27, 373-385.

[119] German DC, Manaye KF, White CL 3rd, Woodward DJ, McIntire DD, Smith WK, Kalaria RN, \& Mann DM (1992) Disease-specific patterns of locus coeruleus cell loss. Ann Neurol, 32, 667-676.

[120] Zarow C, Lyness SA, Mortimer JA, \& Chui HC (2003) Neuronal loss is greater in the locus coeruleus than nucleus basalis and substantia in Alzheimer and Parkinson diseases. Arch Neurol, 60, 337-341.

[121] Dugger BN, Murray ME, Boeve BF, Parisi JE, Benarroch EE, Ferman TJ, \& Dickson DW (2012) Neuropathological analysis of brainstem cholinergic and catecholaminergic nuclei in relation to rapid eye movement (REM) sleep behaviour disorder. Neuropathol Appl NeuroBiol, 38, 142-152.

[122] Jellinger K (1988) The pedunculopontine nucleus in Parkinson's disease, supranuclear palsy and Alzheimer's disease. J Neurol Neurosurg Psychiatry, 51, 540-544.

[123] Gaspar P, \& Gray F (1984) Dementia in idiopathic Parkinson's disease. A neuropathological study of 32 cases. Acta Neuropathol, 64, 43-52.

[124] Agid Y, Javoy-Agid F, \& Ruberg M (1987) Biochemistry of neurotransmitters in Parkinson's disease. In: Marsden CD, \& Fahn ST (eds) Movement Disorders 2nd ed. Butterworths, London, pp. 166-230.

[125] Henderson JM, Carpenter K, Cartwright H, \& Halliday GM (2000) Loss of thalamic intralaminar nuclei in progressive supranuclear palsy and Parkinson's disease: Clinical and therapeutic implications. Brain, 123, $1410-1421$.
[126] Orimo S, Amino T, Itoh Y, Takahashi A, Kojo T, Uchihara T, Tsuchiya K, Mori F, Wakabayashi K, \& Takahashi H (2005) Cardiac sympathetic denervation precedes neuronal loss in the sympathetic ganglia in Lewy body disease. Acta Neuropathol, 109, 583-588.

[127] Orimo S, Takahashi A, Uchihara T, Mori F, Kakita A, Wakabayashi K, \& Takahashi H (2007) Degeneration of cardiac sympathetic nerve begins in the early disease process of Parkinson's disease. Brain Patho, 17, 24-30.

[128] Orimo S, Uchihara T, Nakamura A, Mori F, Ikeuchi T, Onodera O, Nishizawa M, Ishikawa A, Kakita A, Wakabyashi K, \& Takahashi H (2008) Cardiac sympathetic denervation in Parkinson's disease linked to SNCA duplication. Acta Neuropathol, 116, 575-577.

[129] Orimo S, Uchihara T, Nakamura A, Mori F, Kakita A, Wakabayshi K, \& Takahashi H (2008) Axonal alpha-synuclein aggregates herald centripetal degeneration fo cardiac sympathetic nerve in Parkinson disease. Brain, 13, 642-650.

[130] Beach TG, Adler CH, Sue LI, Peirce JB, Bachalakuri J, Dalsing-Hernandez JE, Lue LF, Caviness JN, Connor DJ, Sabbagh MN, \& Walker DG (2008) Reduced striatal tyrosine hydroxylase in incidental Lewy bodies. Acta Neuropathol, 115, 445-451.

[131] Pifl C, Kish SJ, \& Hornykiewicz (2012) Thalamic noradrenaline in Parkinson's disease: Deficits suggest role in motor and non-motor symptoms. Mov Disord, 27, 16181624.

[132] Sitte HH, Pifl C, Rajput AH, Hörtnagl H, Tong J, Lloyd GK, Kish SJ, \& Hornykiewicz O (2017) Dopamine and noradrenaline, but not serotonin, in the human claustrum are greatly reduced in patients with Parkinson's disease. Eur J Neurol, 45, 192-197.

[133] Del Tredici K, \& Braak H (2016) Sporadic Parkinson's disease: Development and distribution of $\alpha$-synuclein pathology. Neuropathol Appl NeuroBiol, 42, 33-50.

[134] Dickson DW, Schmidt ML, Lee VMY, Zhao ML, Yen SH, \& Trojanowski JQ (1994) Immunoreactivity profile of hippocampal CA2/3 neurites in diffuse Lewy body disease. Acta Neuropathol, 87, 269-276.

[135] Kordower JH, Chu Y, Hauser RA, Freeman TB, \& Olanow CW (2008) Lewy body-like pathology in longterm embryonic nigral transplants in Parkinson's disease. Nat Med, 14, 504-506.

[136] Kordower JH, Chu Y, Hauser RA, Olanow CW, \& Freeman TB (2008) Transplanted dopaminergic neurons develop PD pathologic changes: A second case report. Mov Disord, 23, 2303-2306.

[137] Li J-Y, Englund E, Holton JL, Soulet D, Hagell P, Lees AJ, Lashley T, Quinn NP, Rehncrona S, Björkland A, Widner H, Revesz T, Lindvall O, \& Brundin P (2008) Lewy bodies in grafted neurons in subjects with Parkinson's disease suggest host-to-graft disease propagation. Nat Med, 14, 501-503.

[138] Brahic M, Bousset L, Bieri G, Melki R, \& Gitler AD (2016) Axonal transport and secretion of fibrillar forms of $\alpha$-synuclein, A $\beta 42$ peptide and HTTExon 1. Acta Neuropathol, 131, 539-548.

[139] McCann H, Cartwright H, \& Halliday GM (2016) Neuropathology of $\alpha$-synuclein propagation and Braak hypothesis. Mov Disord, 31, 152-160.

[140] Forno LS (1996) Neuropathology of Parkinson's disease. J Neuropathol Exp Neurol, 55, 259-272.

[141] Blesa J, Lanciego JL, \& Obeso JA (2015) Parkinson's disease: Cell vulnerability and disease progression. Front Neuroanat, 9, 125. 
[142] Obeso JA, Rodriguez-Oroz MC, Goetz CG, Marin C, Kordower JH, Rodriguez M, Hirsch EC, Farrer M, Schapira AHV, \& Halliday G (2015) Missing pieces in the Parkinson's disease puzzle. Nat Med, 16, 653-661.

[143] Braak H, \& Del Tredici K (2008) Assessing fetal nerve cell grafts in Parkinson's disease. Nat Med, 14, 483-485.

[144] Savica R, Rocca WA, \& Ahlskog E (2010) When does Parkinson's disease start? Arch Neurol, 67, 98-801.

[145] Lamberts JT, Hildebrandt DN, \& Brundin P (2015) Spreading of $\alpha$-synuclein in the face of axonal transport deficits in Parkinson's disease: A speculative synthesis. Neurobiol Dis, 77, 276-283.

[146] Goedert M, Masuda-Suzukake M, \& Falcon B (2017) Like prions: The propagation of aggregated tau and $\alpha$-synuclein in neurodegeneration. Brain, doi: 10.1093/brain/aww230.

[147] Halliday GM, Hely M, Reid W, \& Morris J (2008) The progression of pathology in longitudinally followed patients with Parkinson's disease. Acta Neuropathol, 115, 409-415.

[148] Braak H, Rüb U, Gai WP, \& Del Tredici K (2003) Idiopathic Parkinson's disease: Possible routes by which vulnerable neuronal types may be subject to neuroinvasion by an unknown pathogen. J Neural Transm, 110, 517-536.

[149] Angot E, Steiner JA, Lema Tomé CM, Ekström P, Mattsson B, Björkland A, \& Brundin P (2012) Alpha-synuclein cell-to-cell transfer and seding in grafted dopaminergic neurons in vivo. PLoS One, 7, e39465.

[150] Desplats P, Lee HJ, Bae EJ, Patrick C, Rockenstein E, Crews L, Spencer B, Masliah E, \& Lee SJ (2009) Inclusion formation and neuronal cell death through neuron-to-neuron transmission of $\alpha$-synuclein. Proc Natl Acad Sci USA, 106, 13010-13015.

[151] Luk KC, Song C, O'Brien P, Stieber A, Branch JR, Brudnen KR, Trojanowski JQ, \& Lee VM (2009) Exogenous $\alpha$-synuclein fibrils seed the formation of Lewy body-like intracellular inclusions in cultured cells. Proc Natl Acad Sci, 106, 20051-20056.

[152] Hansen C, Angot E, Bergström AL, Steiner JA, Pieri L, Paul G, Outeiro RF, Melki R, Kallunki P, Fog K, Li JY, \& Brundin P (2011) $\alpha$-Synuclein propagates from mouse brain to grafted dopaminergic neurons and seeds aggregation in cultured human cells. J Clin Invest, 121, 715-725.

[153] Makin S (2016) The prion principle. Nature, 538, S13S16.

[154] Lee SJ, Desplats P, Sigurdson C, Tsigelny J, \& Masliah E (2010) Cell-to-cell transmission of non-prion protein aggregates. Nat Rev Neurol, 26, 702-706.

[155] Dunning CJR, Reyes JF, Steiner JA, \& Brundin P (2012) Can Parkinson's disease be propagated from one neuron to another? Prog Neurobiol, 97, 205-219.

[156] Hansen C, \& Li JY (2012) Beyond $\alpha$-synuclein transfer: Pathology propagation in Parkinson's disease. Trends Mol Med, 18, 248-255.

[157] Jucker M, \& Walker LC (2013) Self-propagation of pathogenic protein aggregates in neurodegenerative diseases. Nature, 501, 45-51.

[158] Goedert M (2015) Neurodegeneration. Alzheimer's and Parkinson's diseases: The prion concept in relation to assembled $\mathrm{A} \beta$, tau, and $\alpha$-synuclein. Science, 349, 125555.

[159] Goedert M, Clavaguera F, \& Tolnay M (2010) The propagation of prion-like protein inclusions in neurodegenerative diseases. Trends Neurosci, 33, 317-325.
[160] Olanow CW, \& Brundin P (2013) Parkinson's disease and $\alpha$-synuclein: Is Parkinson's disease a prion-like disorder? Mov Disord, 28, 31-40.

[161] Prusiner SB (2013) Biology and genetics of prions causing neurodegeneration. Annu Rev Genet, 47, 601-623.

[162] Aguzzi A, \& Lakkaraju AD (2016) Cell biology of prions and prionoids: A status report. Trends Cell Biol, 26, 4051.

[163] Bousset L, Pieri L, Ruiz-Arlandis G, Gath J, Jensen PH, Habenstein B, Madiona K, Olieric V, Böckmann A, Meier BH, \& Melki R (2013) Structural and functional characterization of two $\alpha$-synuclein strains. Nat Comm, 4, 2575.

[164] Peelaerts W, Bousset L, Van der Peren A, Moskalyuk A, Pulizzi R, Giugliano M, Van den Haute C, Melki R, \& Baekelandt V (2015) $\alpha$-Synuclein strains cause distinct synucleinopathies after local and systemic administration. Nature, 522, 340-344.

[165] Woerman AL, Stöhr J, Aoyagi A, Rampersaud R, Krejciova Z, Watts JC, Ohyama T, Patel S, Widjaja K, Oehler A, Sanders DW, Diamond MI, Seeley WW, Middelton LT, Gentleman SM, Mordes DA, Südhof TC, Giles K, \& Prusiner SB (2015) Propagation of prions causing synucleinopathies in cultured cells. Proc Natl Acad Sci U S A, 112, E4949-4958.

[166] Sacino A, Brooks M, McGarvey HN, McKinney AB, Thomas MA, Levites Y, Ran Y, Golde TE, \& Giasson BI (2013) Induction of CNS $\alpha$-synuclein pathology by fibrillar and non-amyloidogenic recombinant $\alpha$-synuclein. Acta Neuropathol Comm, 1, 38.

[167] Saper CB, Weiner BH, \& German DC (1987) Axonal and transneuronal transport in the transmission of neurological disease: Potential role in system degeneration, including Alzheimer's disease. Neuroscience, 23, 389398.

[168] Funabe S, Takao M, Saito Y, Hatsuta H, Sugiyama M, Ito S, Kanemaru K, Sawabe M, Arai T, Mochizuki H, Hattori N, \& Murayama S (2013) Neuropathologic analysis of Lewy-related $\alpha$-synucleinopathy in olfactory mucosa. Neuropathology, 33, 47-58.

[169] Hawkes CH, Del Tredici K, \& Braak H (2007) Parkinson's disease: A dual hit hypothesis. Neuropathol Appl NeuroBiol, 33, 599-614.

[170] Hawkes CH, Del Tredici K, \& Braak H (2009) The dualhit hypothesis revisited. Ann N Y Acad Sci, 1170, 615622.

[171] Klingelhoefer L, \& Reichmann H (2015) Pathogenesis of Parkinson disease - the gut-brain axis and environmental factors. Nat Rev Neurol, 11, 625-636.

[171a] Sharrad DF, Chen BN, Gai WP, Vaikath N, \& El-Agnaf OM (2016) Rotenone and elevated extracellular potassium concentration induce cell-specific fibrillation of $\alpha$-synuclein in axons of cholinergic enteric neurons in the guinea-pig ileum. Neurogastroenterol Motil, doi: 10.1111/nmo.12985.

[172] Gesser RM, \& Koo SC (1996) Oral inoculation with herpes simplex virus type 1 infects enteric neuron and mucosal nerve fibers within the gastrointestinal tract in mice. J Virol, 70, 4097-4102.

[173] Jang H, Boltz D, Sturm-Ramirez K, Shepherd KR, Jiao X, Webster R, \& Smeyne RJ (2009) Highly pathogenic $\mathrm{H} 5 \mathrm{~N} 1$ influenza virus can enter the central nervous system and induce neuroinflammation and neurodegeneration. Proc Natl Acad Sci U S A, 106, 14063-14068. 
[174] Zoppellaro C, Bin A, Brun P, Banzato S, Macchi V, Castagliuolo I, \& Giron MC (2013) Adenosine-mediated enteric neuromuscular function is affected during herpes simplex virus type 1 infection of rat enteric nervous system. PLoS One, 27, e72648.

[175] Braak H, de Vos RAI, Bohl J, \& Del Tredici K (2006) Gastric $\alpha$-synuclein immunoreactive inclusions in Meissner's and Auerbach's plexuses in cases staged for Parkinson's disease-related brain pathology. Neurosci Lett, 396, 67-72.

[176] Pan-Montojo F, Anichtchik O, Dening Y, Knels L, Pursche S, Jung R, Jackson S, Gille G, Spillantini MG, Reichmann H, et al. (2010) Progression of Parkinson's disease pathology is reproduced by intragastric administration of rotenone in mice. PLoS One, 5, 38762.

[177] Ulusoy A, Rusconi R, Pérez-Revuelta BI, Musgrove RE, Helwig M, Winzen-Reichert B, \& Di Monte DA (2013) Caudo-rostral brain spreading of $\alpha$-synuclein through vagal connections. EMBO Mol Med, 5, 1051-1059.

[178] Holmqvist S, Chutna O, Bousset L, Aldrin-Kirk P, L W, Björklund T, Wang Z-Y, Roybon L, Melki R, \& Li J-Y (2014) Direct evidence of Parkinson pathology spread from the gastrointestinal tract to the brain in rats. Acta Neuropathol, 128, 805-820.

[179] Pan-Montojo F, Schwarz M, Winkler C, Arnhold M, O'Sullivan GA, Pal A, Said J, Marisco V, Verbavatz JM, Rodrigo-Angulo M, Gille G, Funk RH, \& Reichmann H (2012) Environmenal toxins trigger PD-like progression via increased alpha-synuclein release from enteric neurons in mice. Sci Rep, $2,898$.

[180] Phillips RJ, Walter GC, Wilder SL, Baronowsky EA, \& Powley TL (2008) Alpha-synuclein-immunopositive myenteric neurons and vagal preganglionic terminals: Autonomic pathway implicated in Parkinson's disease? Neuroscience, 153, 733-750.

[181] Paillusson S, Clairembault T, Biraud M, Neunlist M, \& Derkinderen P (2012) Activity dependent secretion of alpha-synuclein by enteric neurons. J Neurochem, 125, 512-517.

[182] Blesa J (2013) Parkinson's disease: "Braak" to the future. Mov Disord, 28, 209.

[183] Svensson E, Horváth-Puhó E, Thomsen RW, Djurhuus JC, Pederseen L, Borghammer P, \& Sørensen HT (2015) Vagotomy and subsequent risk of Parkinson's disease. Ann Neurol, 78, 522-529.

[184] Hopkins DA, Bieger D, de Vente J, \& Steinbusch HWM (1996) Vagal efferent projections: Viscerotopy, neurochemistry and effects of vagotomy. Progr Brain Res, 107, 79-96.

[185] Benarroch EE (2007) Enteric nervous system: Functional organization and neurologic implications. Neurology, 69 , 1953-1957.

[186] Cersósimo MG, \& Benarroch EE (2008) Neural control of the gastrointestinal tract: Implications for Parkinson disease. Mov Disord, 23, 1065-1075.

[187] Braak H, Sastre M, Bohl JR, de Vos RA, \& Del Tredici K (2007) Parkinson's disease: Lesions in dorsal horn layer I, involvement of parasympathetic and sympathetic preand postganglionic neurons. Acta Neuropathol, 113, 421429.

[188] Braak H, \& Del Tredici (2016) Potential pathways of abnormal tau and $\alpha$-synuclein dissemination in sporadic Alzheimer's and Parkinson's diseases. Cold Spring Harb Perspect Biol, 8, pii: a023630.
[189] Danzer KM, Ruf WP, Putcha P, Joyner D, Hashimoto T, Glabe C, Hyman BT, \& McLean PF (2011) Heat-shock protein 70 modulates toxic extracellular $\alpha$-synuclein oligomers and rescues trans-synaptic toxicity. FASEB $J$, 25, 326-336.

[189a] Ulusoy A, Phillips RJ, Helwig M, Klinkenberg M, Powley TL, \& Di Monte DA (2017) Brain to stomach transfer of $\alpha$-synuclein via vagal preganglionic projections. Acta Neuropathol, doi: 10.1007/s00401-016-1661-y.

[190] Noorian AR, Rha J, Annerino DM, Bernhard D, Taylor GM, \& Greene JG (2012) Alpha-synuclein transgenic mice display age-related slowing of gastrointestinal motility associated with transgene expression in the vagal system. Neurobiol Dis, 48, 9-19.

[191] Höglinger GU, Alvarez-Fischer D, Arias-Carrión O, Djufri M, Windolph A, Keber U, Borta A, Ries V, Schwartung RK, Scheller D, \& Oertel WH (2015) A new dopaminergic nigro-olfactory projection. Acta Neuropathol, 130, 333-348.

[192] Shipley MT, Halloran FJ, \& de al Torre J (1985) Surprisingly rich projection from the locus coeruleus to the olfactory bulb in the rat. Brain Res, 329, 294-299.

[193] Barnett EM, Cassell MD, \& Perlman S (1993) Two neurotrpic viruses, herpes simplex virus Type 1 and mouse hepatitus virus, spread along different neural pathways from the main olfactory bulb. Neuroscience, 57, 10071025.

[194] Lerner A, \& Bagic A (2008) Olfactory pathogenesis of idiopathic Parkinson disease revisited. Mov Disord, 23, 1076-1084.

[195] Rey NL, Petit GH, Bousset L, Melki R, \& Brundin P (2013) Transfer of human $\alpha$-synuclein from the olfactory bulb to interconnected brain regions in mice. Acta Neuropathol, 126, 555-573.

[196] Doty RL (2008) The olfactory vector hypothesis of neurodegenerative disease: Is it viable? Ann Neurol, 63, 7-15.

[197] Zhou L, Miranda-Saksena M, \& Saksena NK (2013) Viruses and neurodegeneration. Virology J, 10, 172-186.

[198] Marreiros R, Müller-Schiffmann A, Bader V, Selvaraijah S, Dey D, Lingappa VR, \& Korth C (2015) Viral capsid assembly as a model for protein aggregation diseases: Active processes catalyzed by cellular assembly machines comprising novel drug targets. Virus Res, 207, 155-164.

[199] Navarro-Otano J, Gelpi E, Mestres CA, Quintana E, Rauek S, Ribalta T, Santiago V, \& Tolosa E (2013) Alpha-synuclein aggregates in epicardial fat tissue in living subjects without parkinsonism. Parkinsonism Relat Disord, 19, 27-31.

[200] Gelpi E, Navarro-Otano J, Tolosa E Gaig C, Compta Y, Rey MJ, Marti MJ, Hernández I, Valldeoriola F, Reñé R, \& Ribalta T (2014) Multiple organ involvement by alpha-synuclein pathology in Lewy body disorders. Mov Disord, 29, 1010-1018.

[201] Sumikura H, Takao M, Hatsuta H, Ito S, Uchino A, Nogami A, Saito Y, Mochizuki H, \& Murayama S (2015) Distribution of $\alpha$-synuclein in the spinal cord and dorsal root ganglia in an autopsy cohort of elderly persons. Acta Neuropathol Comm, 3, 57.

[202] Del Tredici K, \& Braak H (2012) Spinal cord lesions in sporadic Parkinson's disease. Acta Neuropathol, 124, 643-664.

[203] Aldecoa I, Navarro-Otano J, Stefanova N, Sprenger FS, Seppi K, Poewe W, Cuatrecasas M, Valldeoriola F, Gelpi 
E, \& Tolosa E (2015) Alpha-synuclein immunoreactivity patterns in the enteric nervous system. Neurosci Lett, 602 , 145-149.

[204] Sánchez-Ferro Á, Rábano A, Catalán MJ, RodriguezValcárcel FC, Fernández Diez S, Herreros-Rodriguez J, Garcia-Cobos E, Alvarez-Santullano MM, LopezManzanares L, Mosqueira AJ, Vela Desojo L, Lopez-
Lozano JJ, Lopez-Valdes E, Sanchez-Sanchez R, \& Molina-Arjona JA (2015) In vivo gastric detection of $\alpha$-synuclein inclusions in Parkinson's disease. Mov Disord, 30, 517-524. 